\title{
Determinants of Turnover Intention of Sewing Machine Operators: Case from leading Apparel Company
}

\author{
D M LIYANAGE \\ Department of Management \& Entrepreneurship, Faculty of Management \& Finance, \\ University of Ruhuna, Matara. \\ dilushliyanage@gmail.com \\ B L GALHENA \\ Department of Management \& Entrepreneurship, Faculty of Management \& Finance, \\ University of Ruhuna, Matara. \\ galhena@badm.ruh.ac.lk
}

\begin{abstract}
This paper mainly explores the determinants of turnover intention of the sewing machine operators (SMOs) in apparel industry. The paper aims to identify the impact of SMOs' turnover intention on job satisfaction \& organizational commitment and coping strategies for retention of SMOs. The study used survey method where data were collected through selfadministered structured questionnaire from sample of 200 SMOs employed in a leading garment factory in Sri Lanka. Factors analysis extracted two components of determinants of the turnover intention: controllable and uncontrollable factors. Results revealed that the residency, civil status, recognition, work load, social image, job alternatives and work life balance is the significant predictors of the SMOs' turnover intention. Turnover intention is significantly and negatively correlated with job satisfaction and organizational commitment. Sample t-test found a significant difference between the civil status and residency with the turnover intention. Increasing the salary levels, introduce skilled based incentive schemes, providing more facilities and treating employees in a friendly manner are the most effective retention strategies.
\end{abstract}

Key words: Turnover Intention, Determinants of turnover intention, Job satisfaction, Organizational commitment, coping strategies for retention. 


\section{Introduction}

When considering the contemporary business world it is dynamic in nature and the business organizations which are operated within the scope of this business world are struggling to secure the competitive edge over its rivals. Galhena (2011) stated that the organization which are functioning in its own industrial setting often pay rigorous attention on how to gain competitive advantages over the rivalry among existing firms and new entrants. Barney (1991) classified three basic types of resources which provide competitive advantage as physical capital resources, organizational capital resources and human capital resources. Barney \& Wright (1997)stated that the firm's people are its most important asset. Thus, employee retention is a must to obtain the organizational expected success. Alkandari \& Hammad (2009) contended that the retention of human resources has been shown to be momentous to the development and the accomplishment of the organization's goals and objectives. When dealing with employee retention as Brown et al., (2004) mentioned Labor turnover is an important and pervasive feature of the labor market. Mathis \& Jackson (2006) defined the labor turnover as the process in which employees leave an organization and have to be replaced. However, over time there have been a number of factors that appear to be consistently linked to turnover. An early review article of studies on turnover by Mobley et al., (1979) revealed that age, tenure, overall satisfaction, job content, intentions to remain on the job, and commitment were all negatively related to turnover. Rosse \& Miller (1984) found and Janssen et al., (1998) suggest that, in particular, lack of satisfaction with job aspects like salary, career opportunities and work content were associated with turnover intention.

The central bank annual report (2010) of Sri Lanka specified that the apparel industry remained competitive through increased productivity, improved quality, diversification and gradual recovery in external demand. Kelegama (2005) emphasized that the garment industry in Sri Lanka has been contributing to the livelihood of nearly 1.2 million people. Dheerasinghe (2009) stated that this industry provides more than 330,000 direct employment or 5 per cent of country's total employment. Dheerasinghe (2009) cited the lack of skilled labor and high labor turn over are some of the main challenges facing the Sri Lankan apparel industry.

Mathis \& Jackson (2006) found that turnover is a costly problem and further, argued that, the cost related to the labor turn over can be classified as separation cost, replacement cost, 
training cost, and hidden cost. Thus, the heavy cost is ultimately causes to decrease the profitability and the productivity of the firm. So the present study mainly focus on the determinants of turn over intention of sewing machine operators (SMO) with reference to leading garment factory in Sri Lanka. The company maintained records shows that there is a specific pattern of turnover rates. When concerning the monthly turn over in each and every year the high turnover is recorded in the month of May and June. That peak slowly goes down until the month of December and in the months of January. In February the turnover is again increasing but in March \& April it goes down. This paper it is aimed to determine the determinants for such type of pattern in turnover and its consequences for work related outcomes.

\section{Research Problem}

Boxall et al., (2003) mentioned and McElroy et al., (2001) suggested that although there are occasional arguments to the contrary, there is evidence that high levels of voluntary turnover adversely affect business unit performance. Khatri et al., (1999) mentioned and Barnett (1995), Chang (1996) Syrett (1994) suggest that voluntary turnover is a major problem for companies in many Asian countries such as HongKong, South Korea, Malaysia, Singapore, and Taiwan and Sri Lanka.

Dheerasinghe (2009) pointed out that the Garment industry has an important place in Sri Lanka's economy. It has become Sri Lanka's largest export industry. But as Dheerasinghe (2009) pointed out the major problem the garment industry is facing is the problems in developing and maintaining the required manpower.

Joshi (2002) cited that ninety percent of the garment workers are female, which signifies unprecedented entry of female workers in manufacturing activities. Dheerasinghe (2009) stressed that most of the female workers leave the industry after marriage while a considerable number of trained workers leave the industry for foreign employment. The average labour turnover worked out per factory is about 60 per cent per annum. Taking the labour migration within the industry into account, the net number of persons leaving the industry each year is estimated as 25 per cent. So there is a high potential to quit the factory.

Brown et al., (2004) highlighted that labor turnover affects both workers and firms. Workers experience disruption, the need to learn new job-specific skills and find different career 
prospects. Firms, on the other hand, lose job-specific skills, suffer disruption in production and incur the costs of hiring and training new workers.

The company which was selected for this study maintained records shows that there is a specific pattern of turnover rates. The company maintaining $2.5 \%-3.5 \%$ annual turnover rate and when concerning the monthly turn over in each and every year the high turnover is recorded in the month of May and June. That peak slowly goes down until the month of December and in the months of January. In February the turnover is again increasing but in March \& April it goes down. Table No: 1 shows the turnover rates of the selected company. Thus this paper address two research question (1) why the level of turnover intention is high among the SMOs? And what are the significant determinants of turnover intention (2) what is the impact of turnover intention of SMOs on work related outcome such as job satisfaction and organizational commitment.

Table 1: Analysis of turnover (summary)

\begin{tabular}{lllll}
\hline Month & $\mathbf{2 0 0 8}$ & $\mathbf{2 0 0 9}$ & $\mathbf{2 0 1 0}$ & $\mathbf{2 0 1 1}$ \\
January & 44 & 131 & 105 & 65 \\
February & 40 & 92 & 75 & 71 \\
March & 15 & 62 & 58 & 57 \\
April & 55 & 60 & 30 & 39 \\
May & 105 & 129 & 111 & 118 \\
June & 106 & 161 & 91 & 82 \\
July & 81 & 88 & 98 & 61 \\
August & 76 & 115 & 64 & 71 \\
September & 122 & 122 & 82 & 60 \\
October & 95 & 80 & 60 & 64 \\
November & 90 & 84 & 64 & 50 \\
December & 80 & 75 & 38 & 46 \\
Total & 909 & 1199 & 876 & 784 \\
AVG No. of SMO & 2775 & 2818 & 2863 & 2745 \\
Turnover \% & $2.73 \%$ & $3.56 \%$ & $2.55 \%$ & $2.60 \%$ \\
\hline
\end{tabular}

Source: Company records 2011 


\section{Objectives of the research}

The objectives that aim to fulfill, can be stated briefly as follows

1. To identify the factors which cause to the Sewing Machine Operators turnover intention.

2. To identify the impact of turnover intention on commitment and job satisfaction.

3. Suggest strategic solutions to retain SMOs within the apparel industry.

\section{Conceptual Framework}

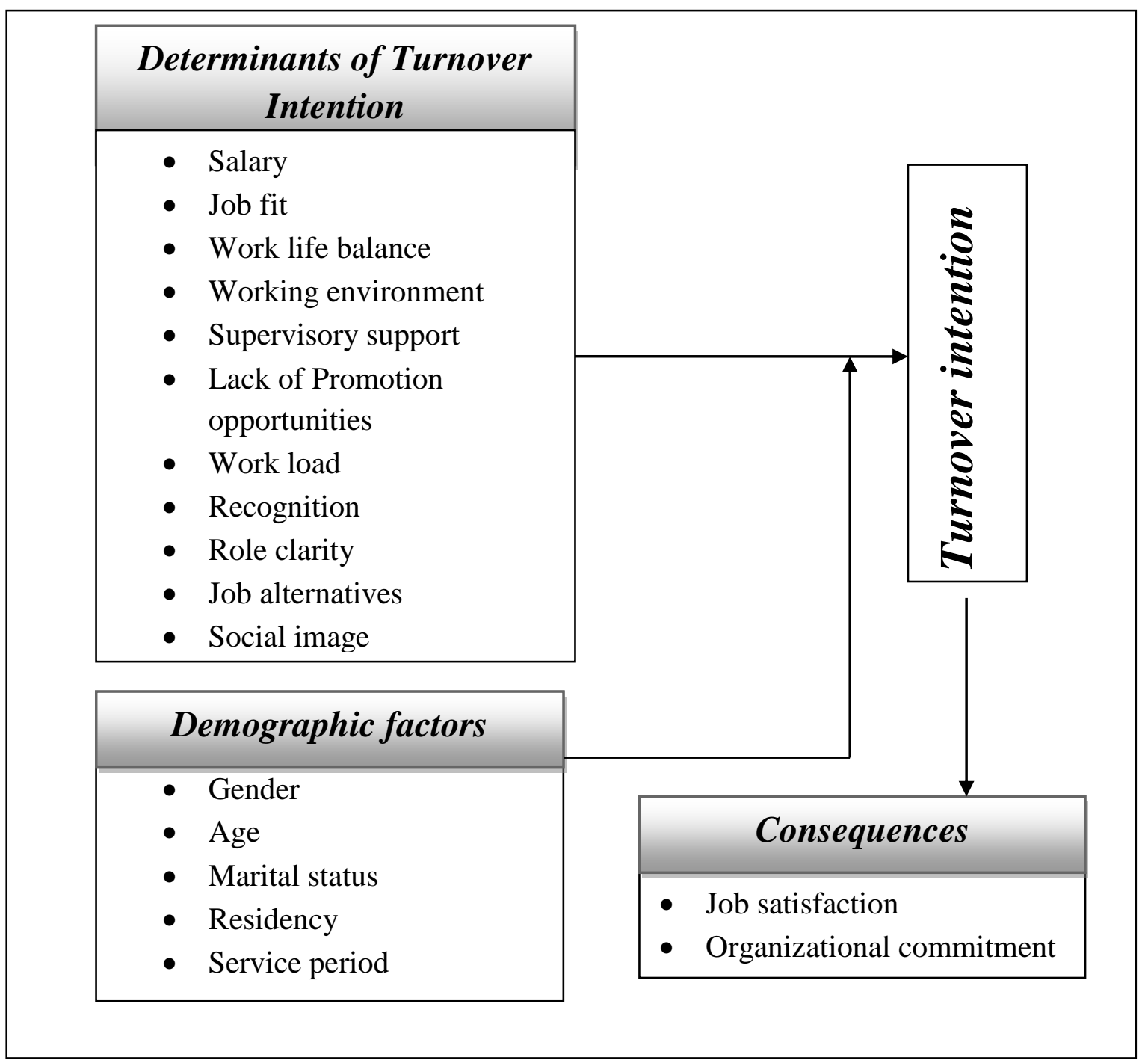

Figure 1: Conceptual frame work

As the graphical illustration of the conceptual framework (figure 1) the turnover intention occurs due to variety of sub determinants and those were identified according to the literatures exists. Under the determinants of turnover intention age, tenure, education level, 
salary, job fit, work life balance, working environment, supervision, recognition, promotion, workload, role clarity alternative jobs and social image are considered.

A turnover intention may be emerged with the impact of this above mentioned variables. The frame work further identifies the relationship in between the turnover intention and its outcomes. As illustrated below the outcomes are organizational commitment and the job satisfaction.

\section{Literature Review}

\section{Turnover}

Mathis \& Jackson (2006) defines the turnover is the process in which employees leave an organization and have to be replaced. Like absenteeism, turnover is related to the job satisfaction and organizational commitment. Janssen et al., (1998) suggested and Breukelen (1988)defined Job turnover as 'voluntarily leaving the organization'. However, Mathis \& Jackson (2006) argued that the turnover is not only a voluntary leave but it includes involuntary turnover in broader sense.

\section{Turnover Intention \& Determinants of Turnover Intention}

Joshi (2002) pointed out that there are a number of reasons attributed to the high rates of labor turnover and absenteeism. Comber et al., (2006) defined Turnover intention (or intent to leave/stay) is consequently considered as an outcome of affective variables (such as job satisfaction) rather than actual turnover, which may be mediated by other variables such as age and tenure. Houkes et al., (2003) Iverson \& Roy (1994) Rosse \& Miller, (1984) Breukelen, (1989) suggested that, pertaining to work related factors, particularly conditions of employment (e.g. salary, career opportunities) are important causes of turnover intention. When employees consider their career opportunities within the organization as limited or absent (unmet career expectations), a withdrawal reaction may be evoked in order to cope with the frustrations.

Al-Qahtani (2009) argued that the turnover is impacted by the demographic variables such as age, educational level etc. and further stated and Mobley et al., (1979) cited that "Reviewers of the turnover literature report a consistent negative relationship between age and turnover younger employees have a higher probability of leaving". Robert and John (2006) pointed out the reasons for turnover intention include employee moves out of the geographical area, 
employee decides to stay home with young children or elder relatives, employees spouse is transferred, and the employee is a student worker who graduates from a college.

Blau (1987) Rosse \& Miller (1984) found that, in particular, lack of satisfaction with salary was associated with turnover intention. Bawa et al., (2005) mentioned and Huselid's (1995) found that perceptions of Human Resource (HR) practices such as job security and compensation level are important determinants of employee turnover. A poor working environment is among the main reasons. Workers' facilities greatly vary among the garment factories, with only a few of the 'stronger' enterprises having satisfactory working conditions. Differences in allowances and facilities among factories have resulted in the continual movement of labor to enterprises where working conditions are better. Similarly, Mowday et al., (1982) mentioned the negative relationship between working conditions and voluntary turnover has received attention from many researchers indicating the propensity of employees quitting their jobs when working conditions are not conducive.

Blau (1987) Rosse\& Miller (1984) found that, in particular, lack of satisfaction with career opportunities was associated with turnover intention. Gaertner (2000) suggest the employees are having high potential to leave if the job requirements are conflicting, unclear or if opportunities for growth, skill development, and promotions are lacking.

Blau (1987) and Rosse \& Miller (1984) found that in the case of voluntary turnover, many researchers hold the position that employees leave their jobs when their needs are not being satisfied by their present job and an alternative job becomes available. Griffeth et al., (2000) Perceived employment alternatives modestly predict turnover. Unemployment rates influence the perceived availability of alternatives and hence the expected utility of job searches activities. Further Joshi (2002) stated that a poor social image of factory workers is another factor contributing to high labor turnover. Due to the bad reputation the industry has gained for harassment of women workers and the poor working conditions, the factory worker has a social stigma. These factors too have led to high labor turnover, which in turn has impeded the productivity of labor and affected Sri Lanka's international competitiveness.

\section{Job Satisfaction and Employee Turnover Intention}

Al-qahtani (2009) stated that when the job provides what the employee like or values, satisfaction is increased. And on the opposite side, when employee belief the job is not providing what he likes, satisfaction is decreased. There are many aspects of job satisfaction 
are important to understand satisfaction and its relationship with turnover. Satisfaction is different between people based on their interests. Some individuals like repetitive jobs, rotating shifts, and no overtime. Conversely others like involving in decision making, flexible work hours, and high-incentive earnings. Khatri et al., (1999) mentioned that consistent and negative relationship existed between job satisfaction and turnover as dissatisfied employees are more likely to leave an organization than satisfied ones.

\section{Organizational Commitment and Employee Turnover Intention}

Cohen (1993) and Steers et al., (1982) contended that highly committed employees wish to remain with their employing organizations. Khatri et al., (1999) highlighted the importance of organizational commitment in explaining turnover. Since then organizational commitment has been frequently explored in the turnover literature, and like job satisfaction, has been shown to be negatively related to turnover.

\section{Method}

The present study mainly focuses on understanding the factors which affect to the turnover intention of sewing machine operators (SMO) and the consequences of turnover intention. A structured questionnaire was used to collect primary data. The total sample consisted with 200 SMOs, including 20 male SMOs. As Joshi (2002) cited that ninety percent of the garment workers are female, the sample was also selected in accordance with that by including 180 female SMOs' and 20 male SMOs'.

The questionnaire mainly comprised with five parts which discussed the demographic factors, determinants of turnover intention, turnover intention, and consequences of turnover intention in terms of commitment and satisfaction and potential retention strategies. The questionnaire was distributed to the respondents by giving them a time frame (one day interval) to submit it to the researcher and it consisted with both open-ended and closed questions. It was based on seven point rating scale (Likert scale). The sample of $200(n=200)$ SMOs selected from the customer group which has a high turnover ratio in the considered garment factory. To select the sample out of the total number of the cluster Systematic Sampling method was used. 


\section{Measuring Instruments}

Variables of the study were measured using different valid and reliable scales. Thirteen items were included with in questionnaire as the determinants of turnover intention which were selected from the literature review and for the measuring purpose the seven point Lickert scale was used and the variables such as salary job fit and the work life balance was measured by using the scale ranging from (7) "strongly disagree" to (1) "strongly agree". "I am satisfied with the salary I am provided", "I can manage my personal life and the working life" were the examples for the items used in the study to measure the individual variables. To measure the turnover intention scales from Galhena (2009) adopted with slight modifications and measured the scale ranging from (1) "strongly disagree" to (7) "strongly agree". The sample of items includes, "I am frequently alert on the vacancies published in newspapers and poster etc". The demographic attributes such as age, gender, civil status and tenure were also obtained. Turnover intention was measured with items based on seven-point Likert scales ( 1 = "strongly disagree" to $7=$ "strongly agree"). Organizational commitment scale adopted form Mowday, et al., (1979) and job satisfaction scale adopted from Tremblay et al., (1995) were used to measure work related outcomes.

\section{Hypothesis}

H1: There is a significance difference of turnover intention, job satisfaction and organizational commitment among male and female SMOs.

$\mathrm{H} 2$ : There is a significance difference of turnover intention, job satisfaction and organizational commitment among married and single SMOs.

H3: There is a significance difference of turnover intention, job satisfaction and organizational commitment among service periods of the SMOs.

H4: There is a significance difference of turnover intention, job satisfaction and organizational commitment among residency of the SMOs.

H5: There is a significance difference of turnover intention, job satisfaction and organizational commitment among SMOs' age.

H6: Turnover intention, job satisfaction and organizational commitment are significantly negatively correlated. 


\section{Results and Discussion}

Demographic variables were analyzed first and 62\% of SMOs are in young age (18-30), 36\% are in between 30 to 45 . Only $1.5 \%$ of SMOs fallen into the matured category. Out of the sample majority of the SMOs (90\%) are female and only $10 \%$ employees are males. Approximately $69.5 \%$ of respondents are married and rest of $30.5 \%$ is single. When dealing with the service period $63 \%$ are worked less than five years and $27 \%$ of SMOs have worked for more than five years as a SMO. Majority of SMOs $(93.5 \%)$ resides near to the factory and rest of the sample $(6.5 \%)$ resides far away from the factory.

\section{Determinants of Turnover Intention}

Thirteen items which were identified through the literature review as the determinants of turnover intention and before implementing the factor analysis with the use of Principal Components Analysis (PCA) by using SPSS the suitability for the factor analysis was done. According to the correlation matrix more variables baring coefficients 0.3 and above. KaiserMayer-Olkin measure of sample adequacy (KMO value) was 0.828 which exceed the minimum value of 0.6 in determining factorability (Sullivan 2009). The Bartlett's test of Sphericity accounts for significant value of zero $(\mathrm{p}=0.000)$ which supported to the factorability test. Factor analysis using the extraction method of principal component analysis with Varimax rotation identified two factors with the eigenvalue is higher than 1.0 and the cumulative total variance explained $50.6 \%$. The classified factors are categorized in to two categories namely controllable and uncontrollable. Reliability of the variables also measured using the Cronbach's alpha and values are illustrated in Table 2.

Table 2: Factor analysis results

\begin{tabular}{|c|c|c|c|}
\hline Factors & Alpha & 1 & 2 \\
\hline Controllable factors & 0.88 & & \\
\hline Recognition & & 0.809 & \\
\hline Role clarity & & 0788 & \\
\hline Supervisory Support & & 0.771 & \\
\hline Work Load & & 0.769 & \\
\hline Promotion Opportunities & & 0.743 & \\
\hline Working Environment & & 0.691 & \\
\hline Salary & & 0.626 & \\
\hline
\end{tabular}


Job Fit

Total variance explained

Uncontrollable factors

Social Image

Job Alternatives

Group Incentive

Short Term Objectives

Work Life Balance

Total variance explained
0.566

36.7

0.60

0.719

0.656

0.622

0.353

0.337

14.0

Testing Hypothesis 01: Independent sample t-test-Gender

An independent sample t-test was performed to compare the differences of turnover intention, job satisfaction and organizational commitment among gender groups, civil status, residency and service period. No significant different was found in between male and females with any of the variables. So there is no significant difference between male and female and turnover intention $(\mathrm{t}=-0.452, \mathrm{p}=0.652)$, job satisfaction $(\mathrm{t}=0.373, \mathrm{p}=0.709)$ and organizational commitment $(\mathrm{t}=-0.076, \mathrm{p}=0.940)$ (Table 03). Based on the finding the hypothesis 1 is rejected.

Table 3: Independent sample t-test: Gender

\begin{tabular}{llllllll}
\hline Variables & Gender & $\mathbf{N}$ & Mean & Std. devi: & Sig. & t & Sig.(2-tailed \\
\hline Turnover intention & Female & 180 & 3.76 & 1.05 & 0.283 & -0.452 & 0.652 \\
& Male & 20 & 3.87 & 0.89 & & & \\
Job satisfaction & Female & 180 & 5.30 & 1.00 & 0.124 & 0.373 & 0.709 \\
& Male & 20 & 5.22 & 0.79 & & & \\
Organizational & Female & 180 & 5.57 & 1.09 & 0.796 & 0.076 & 0.940 \\
commitment & Male & 20 & 5.55 & 1.06 & & &
\end{tabular}

Testing Hypothesis 02: Independent sample t-test- civil status

Table 04 shows the results of independent sample t-test for civil status and found a significant difference in between the married and single employees with the turnover intention $(\mathrm{t}=-1.968$, $\mathrm{p}=0.05)$. The hypothesis 02 is accepted in this regards. The null hypothesis has to be accepted since there is no significant difference between the married and single status and the job satisfaction $(t=1.697, p=0.092)$ and organizational commitment $(t=-1.066, p=0.288)$. 
Table 4: Independent sample t-test: civil status

\begin{tabular}{llrlllll}
\hline Variables & Civil status & N & Mean & Std. devi & Sig. & t & Sig.(2-tailed \\
\hline Turnover & Married & 139 & 3.67 & 1.04 & 0.987 & -1.968 & 0.05 \\
intention & Single & 61 & 3.98 & 1.02 & & & \\
Job satisfaction & Married & 139 & 5.37 & 1.04 & 0.003 & - & 0.092 \\
& Single & 61 & 5.13 & 0.84 & & 1.697 & \\
Organizational & Married & 139 & 5.52 & 1.16 & 0.022 & - & 0.288 \\
commitment & Single & 61 & 5.68 & 0.91 & & -1.066 & \\
& & & & & & &
\end{tabular}

Testing Hypothesis 03: Independent sample t-test -Service period

There is no significant differences between the period of service (i.e.: short period and long period) and the turnover intention $(\mathrm{t}=1.373, \mathrm{p}=0.171)$, job satisfaction $(\mathrm{t}=0.188, \mathrm{p}=$ $0.851)$ and the organizational commitment $(\mathrm{t}=-0.202, \mathrm{p}=0.840)$. The hypothesis 03 is rejected in this regard.

Table 5: Independent sample t-test: Service period

\begin{tabular}{llllllll}
\hline Variables & Service period & N & Mean & Std. devi: & Sig. & t & $\begin{array}{l}\text { Sig. (2- } \\
\text { tailed) }\end{array}$ \\
\hline $\begin{array}{l}\text { Turnover } \\
\text { intention }\end{array}$ & Less than five years & 126 & 3.84 & 1.01 & 0.947 & 1.373 & 0.171 \\
Job & More than five years & 74 & 3.64 & 1.08 & & & \\
satisfaction & Less than five years & 126 & 5.31 & 0.92 & 0.005 & - & 0.188 \\
$\begin{array}{l}\text { Organizational } \\
\text { commitment }\end{array}$ & Less than five years & 126 & 5.56 & 1.10 & 0.651 & - & 0.840 \\
& More than five years & 74 & 5.59 & 1.08 & & 0.202 & \\
\end{tabular}

Testing Hypothesis 04: Independent sample t-test -residency

There is a significant difference between the two distances/ residency (short distance and long distance) regarding the turnover intention $(t=2.12, p=0.035)$. Since the $p<0.05$ the hypothesis 4 is accepted. But there is no significant difference between the two distant regarding job satisfaction $(\mathrm{t}=-0.483, \mathrm{p}=0.630)$ and organizational commitment $(\mathrm{t}=1.420, \mathrm{p}$ $=0.157)$. So the hypothesis 4 is rejected. 
Table 6: Independent sample t-test: Residency

\begin{tabular}{llllllll}
\hline Variables & Residency & N & Mean & Std. devi: & Sig. & t & Sig.(2-tailed \\
\hline Turnover & Short distant & 187 & 3.81 & 1.02 & 0.755 & 2.12 & 0.035 \\
intention & Long distant & 13 & 3.18 & 1.13 & & & \\
Job satisfaction & Short distant & 187 & 5.29 & 0.99 & 0.432 & -0.483 & 0.630 \\
& Long distant & 13 & 5.42 & 1.03 & & & \\
Organizational & Short distant & 187 & 5.60 & 1.09 & 0.533 & 1.420 & 0.157 \\
commitment & Long distant & 13 & 5.15 & 1.05 & & & \\
& & & & & & & \\
\hline
\end{tabular}

Testing Hypothesis 05: One way ANOVA tests for age of SMOs

A one way ANOVA test was conducted to identify the relationship between age and the turnover intention, job satisfaction and organizational commitment. Results show that there is no statistically significance difference between the age categories and turnover intention, job satisfaction and the organizational commitment. Since hypothesis 5 is rejected.

Table 7: Results of ANOVA test

\begin{tabular}{|c|c|c|c|c|c|}
\hline Variables & $\begin{array}{l}\text { Sig.-Homogeneity } \\
\text { test }\end{array}$ & $\begin{array}{l}\text { Sig.- } \\
\text { ANOVA test }\end{array}$ & \multicolumn{2}{|c|}{ Mean differences } & $\begin{array}{l}\text { Multiple } \\
\text { comparison }\end{array}$ \\
\hline $\begin{array}{l}\text { Turnover } \\
\text { intention }\end{array}$ & 0.135 & 0.725 & $\begin{array}{l}\text { Young } \\
\text { Matured } \\
\text { Old }\end{array}$ & $\begin{array}{l}\text { Matured } \\
\text { Old } \\
\text { Young } \\
\text { Old } \\
\text { Young } \\
\text { Matured }\end{array}$ & $\begin{array}{l}0.718 \\
0.991 \\
0.718 \\
0.944 \\
0.991 \\
0.944\end{array}$ \\
\hline $\begin{array}{l}\text { Job } \\
\text { satisfaction }\end{array}$ & 0.261 & 0.779 & $\begin{array}{l}\text { Young } \\
\text { Matured } \\
\text { Old }\end{array}$ & $\begin{array}{l}\text { Matured } \\
\text { Old } \\
\text { Young } \\
\text { Old } \\
\text { Young } \\
\text { Matured }\end{array}$ & $\begin{array}{l}0.962 \\
0.806 \\
0.962 \\
0.771 \\
0.806 \\
0.771\end{array}$ \\
\hline $\begin{array}{l}\text { Organizationa } \\
1 \text { commitment }\end{array}$ & 0.024 & 0.331 & $\begin{array}{l}\text { Young } \\
\text { Matured } \\
\text { Old }\end{array}$ & $\begin{array}{l}\text { Matured } \\
\text { Old } \\
\text { Young } \\
\text { Old } \\
\text { Young } \\
\text { Matured }\end{array}$ & $\begin{array}{l}0.631 \\
0.532 \\
0.631 \\
0.393 \\
0.523 \\
0.393\end{array}$ \\
\hline
\end{tabular}




\section{Correlation analysis}

Pearson correlation computed to identify correlation between turnover intention and work related outcome variables i.e. job satisfaction and organizational commitment. Significant negative correlation observed between turnover intention and the job satisfaction and organizational commitment.

Table 8: Results of correlation analysis

\begin{tabular}{lcl}
\hline Variables & Turnover intention & Sig: \\
\hline & -0.68 & 0.00 \\
Job satisfaction & -0.60 & 0.02 \\
Organizational commitment & & \\
\hline
\end{tabular}

Regression Analysis

A multiple regression analyze was conducted to identify the contribution and the significance level of each independent variables and dependent variable. It is revealed that there is a significant relationship between the residency and the turnover intention but no significant relationship is found between age and service period. And also it is identified that there is a significant relationship between recognition, $(\beta=-0.239, \mathrm{p}<0.05)$, work load, $(\beta=\mathrm{p}<0.05)$ with the turnover intention. When considering the controllable factors. It is identified that there is a highly significant relationship between the turnover intention and the social image, $(\beta=0.293, p<0.05)$ work life balance $(\beta=-0.273, p<0.05)$ and job alternatives $(\beta=-0.306$, $\mathrm{p}<0.05$ ) when considering the uncontrollable factors.

Table 9: Results of regression analysis

\begin{tabular}{lllllc}
\hline Independent variable & B & $\begin{array}{l}\text { Standardized } \\
\text { coefficient }\end{array}$ & $\begin{array}{l}\text { Standard } \\
\text { error }\end{array}$ & $\begin{array}{l}\text { t-value } \\
\text { level }\end{array}$ \\
\hline $\begin{array}{l}\text { Demographic variables } \\
\text { Age }\end{array}$ & & & & & \\
Service period & -0.910 & -0.046 & 0.142 & -0.641 & 0.522 \\
Residency & -0.170 & -0.079 & 0.163 & -1.041 & 0.299 \\
& -0.649 & -0.154 & 0.298 & -2.177 & 0.030 \\
Controllable factors & & & & & \\
Recognition & -0.199 & $-0.239 * *$ & 0.099 & -2.022 & 0.045 \\
Role clarity & -0.043 & -0.047 & 0.094 & -0.456 & 0.649 \\
\hline
\end{tabular}




\begin{tabular}{llllll}
\hline Supervisory Support & 0.014 & 0.020 & 0.078 & 0.187 & 0.852 \\
Work Load & 0.203 & $0.236^{* *}$ & 0.092 & 2.207 & 0.029 \\
Promotion Opportunities & -0.034 & -0.042 & 0.077 & -0.439 & 0.661 \\
Working Environment & -0.057 & -0.071 & 0.078 & -0.726 & 0.469 \\
Salary & -0.046 & -0.054 & 0.072 & -0.636 & 0.526 \\
Job Fit & 0.055 & 0.074 & 0.069 & 0.790 & \\
& & & & & 0.430 \\
Uncontrollable factors & 0.271 & $0.293^{* * *}$ & 0.075 & 3.612 & 0.000 \\
Social Image & 0.245 & $-0.306^{* * *}$ & 0.056 & -4.359 & 0.814 \\
Job Alternatives & 0.010 & 0.016 & 0.043 & 0.223 & 0.003 \\
Group Incentive & -0.011 & -0.018 & 0.048 & -0.236 & \\
Short Term Objectives & -0.233 & $-0.279^{* * *}$ & 0.076 & -3.050 & \\
Work Life Balance & & & &
\end{tabular}

Additionally the present study emphasized the coping strategies to deal with turnover intention. Data collected through open ended questions in the survey classified in to three main sub categories on the basis of the nature of the coping strategy: (1) coping strategies for improving the basic life standard of SMOs, (2) coping strategies for improving the psychological movements of SMOs, (3) coping strategies for improving the skills of SMOs. Most of the respondents suggest that increasing the salary level of SMOs, introducing a beneficial production incentive scheme, treating employees in a friendly manner, high supervisory support and having a special training program focus on attitudinal changes of employees as effective retention strategy.

\section{Conclusion}

The primary purpose of this study was to identifying determinants of the turnover intention among SMO in apparel industry. Based on the analysis following conclusions are made. Residency, civil status, recognition, work load, social image, job alternatives, work life balance is the significant predictors of the turnover intention. The turnover intention and the consequences of the turnover intention that is job satisfaction and the organizational commitment are significantly negatively correlated. Increasing the salary levels, introduce skilled base incentive schemes, providing more facilities and treating employees in a friendly manner are the most effective retention strategies. 


\section{References}

Alkandari, Q., \&Hammad, A.A. (2009).Employees retention in private sector: an exploratory study in the state of Kuwait. Open university, Malaysia

Al-Qahtani, A.J. (2009). Turnover: Causes and Means to Retain, Case study for Sabic Affiliate (SADAF).Open University, Malaysia.

Barney, J. \& Wright, M., (1997).OnBecoming a Strategic Partner: The Role of Human Resources in Gaining Competitive Advantage(Center for Advance Human Resource Studie, Cornel lves Hall, Ithaca, USA). Retrieve from http://digitalcommons.ilr.cornell.edu/cahrswp/150.

Bawa, M.A., \&Jantan, M. (2005). Human resource practices as determinants of employee turnover: an empirical investigation.Vol. 10, 2, 69-80, Retrieved from Asian Academy of Management Journal.

Blau, G.J., \&Boal. K. B. (1987). Conceptualizing How Job Involvement and Organizational Commitment Affect Turnover and Absenteeism. Academy of Management Review, 12 (2).288-300.

Brown, S., Garino, G., \& Martin, C. (2009).Labour Turnover and Firm Performance, Theory and Evidence from the 2004 UK Workplace Employee Relations Survey.Economic Modeling.26(3).689-695.Retrieved

fromhttp://www.sciencedirect.com/science/article/pii/S0264999309000273

Central bank of Sri Lanka. (2010). Economic, price and financial system stability, outlook and policies (Annual report 2010) Sri Lanka: Central Bank of Sri Lanka

Cohen, A. (1993). Organizational Commitment and Turnover: A Meta-Analysis. The Academy of Management Journal, 36 (5), 1140-1157.

Dheerasinghe, R. (2009). Garment Industry in Sri Lanka Challenges, Prospects and Strategies. Staff studies, 33(1\&2). 33-72.Doi: 10.4038/ss.v33i1.1246

Galhena, B.L. (2009). Comparison of job related variables between temporary and permanent academics. Processing of ICBI, University of Kelaniya 
Janssen, P.P.M., Jonge, J.D. \& Bakker, A.B. (1999). Specific determinants of intrinsic work motivation, burnout and turnover intentions: a study among nurses. Journal of Advanced Nursing, 29(6), 1360-1369.

Joshi, G. (2002). Garment industry in South Asia Rags or riches? Competitiveness, productivity and job quality in the post-MFA environment. South Asia Multi disciplinary Advisory Team.

Kelegama, S. (2005).Ready-Made Garment Industry in Sri Lanka: Preparing to Face the Global Challenges. Asia-Pacific Trade and Investment Review, 1(1), 51-67.

Khatri. N., Budhwar, P., \& Fern. C.T., (1991). Employee turnover: Bad attitude or poor management. Retrieved from: www3.ntu.edu.sg/nbs/sabre/working_papers/12-99.pdf

Mathis, R.L., \& Jackson, J.H. (2006).Human Resource Management (1 $1^{\text {th }}$ ed.).Omaha.

Mobley, W. H., Griffeth, R. W., Hand, H. H. \&Meglino, B. M. (1979). Review and conceptual analysis of the employee turnover process, Psychological Bulletin, 86 (3), 493-522. 